\title{
The efficacy of intravitreal antivascular endothelial growth factor as primary treatment of retinopathy of prematurity: Experience from a tertiary hospital
}

\author{
H Kana, MB BCh, FC Ophth; I Mayet, MB ChB, FC Ophth, FCS (Edin); D Soma, MB ChB, FC Ophth, MMed (Ophth); \\ H Dawood Alli, MB BCh, FC Ophth, MMed (Ophth); S Biddulph, MB BCh, FC Ophth
}

St John Eye Hospital-Chris Hani Baragwanath Academic Hospital and Department of Ophthalmology, Faculty of Health Sciences, University of the Witwatersrand, Johannesburg, South Africa

Corresponding author: H Kana (dockana@gmail.com)

\begin{abstract}
Background. Retinopathy of prematurity (ROP) is a vasoproliferative disease affecting premature babies and a major cause of blindness in childhood. Appropriate screening and treatment can prevent blindness.

Objective. To report on the efficacy of using antivascular endothelial growth factor (bevacizumab) as first-line therapy in ROP.

Methods. This was a retrospective analysis of patients with ROP treated at St John Eye Hospital, Johannesburg, South Africa, over a 3-year period. Outcome measures were the clinical response to intravitreal bevacizumab (IVB) as well as the economic impact of IVB therapy.

Results. Twenty-three patients were treated for active ROP or type 1 disease, in 44 eyes. Two patients required treatment in one eye only. The mean birth weight of these patients was $1074 \mathrm{~g}$ (range 810 - 1480). Response to treatment outcome was available for 22 patients (43 eyes). The mean follow-up period was 9 months (range 1 - 18). Forty-one eyes (95.3\%) showed complete regression or non-progression of the disease. Two eyes (one eye each in two patients) progressed to advanced disease. There were no short-term adverse events. A cost-effective model showed that IVB treatment was much more economical than laser therapy.

Conclusion. IVB is a safe and effective first-line treatment for ROP and should be considered in resource-limited centres.
\end{abstract}

S Afr Med J 2017;107(3):215-218. DOI:10.7196/SAMJ.2017.v107i3.11080

Retinopathy of prematurity (ROP) is a vasoproliferative retinal disorder affecting premature, low-birth-weight infants and accounts for $10.2 \%$ of children admitted to schools for the blind in South Africa (SA). ${ }^{[1]}$ The World Health Organization's VISION 2020 mission has recognised ROP as an important and preventable cause of childhood blindness. ${ }^{[2]}$ Screening and appropriate treatment are imperative in this endeavour.

The findings of a multicentre trial of cryotherapy for ROP (CRYO$\mathrm{ROP})^{[3]}$ have shown the benefit of treatment with cryotherapy in reducing unfavourable visual outcome by $50 \%$ in infants at risk of proliferative retinopathy. Subsequently, the Early Treatment of ROP (ETROP) study ${ }^{[4]}$ showed laser ablation to be superior to cryotherapy. Laser treatment remains the gold standard in treating threshold disease in ROP. The discovery of antivascular endothelial growth factor (anti-VEGF) in the treatment of colonic cancer ${ }^{[5]}$ and its subsequent use in various proliferative vascular retinal conditions such as retinal vein occlusion ${ }^{[6]}$ and diabetic retinopathy ${ }^{[7]}$ have led to a paradigm shift in the management of these conditions. As an extension of this, anti-VEGF (bevacizumab) therapy has been used in treating ROP, initially as an adjunct to laser therapy and subsequently as primary treatment. Several case studies have reported favourable outcomes using bevacizumab therapy..$^{[8-10]}$

In our hospital laser treatment, when indicated, is performed under general anaesthesia and although effective, it is time consuming and necessitates overnight observation in a high-care facility. Availability of beds in high care is often problematic. Intravitreal bevacizumab (IVB) can be administered under local anaesthesia, and high-care monitoring is not necessary.

\section{Objective}

To report our experience with the use of IVB injections as primary treatment of ROP.

\section{Methods}

This retrospective observational study analysed the efficacy of IVB in the treatment of ROP. The records of all patients with ROP who were treated with IVB injections over a 3-year period (2013 - 2015) at St John Eye Hospital, Johannesburg, SA, were reviewed. During that period, all infants were treated exclusively with IVB and none with laser photocoagulation. The hospital screens $\sim 640$ premature infants per year, using the screening guidelines recommended by the Royal College of Ophthalmology (UK) (Table 1). Indication for treatment is active disease as defined in the ETROP study ${ }^{[4]}$ (Table 2).

After informed consent had been obtained from the parents, all patients were given an intravitreal injection of bevacizumab (Avastin; Genentech), a monoclonal anti-VEGF antibody, as an off-label but accepted treatment method. The drug was drawn from a standard multidose vial (100 mg/4 mL ampoule). Topical anaesthesia and povidone iodine drops were instilled into the eyes before the injection. No sedation was given. An anaesthetist is always available in theatre, but was not required. A dose of $0.625 \mathrm{mg}$ $(0.025 \mathrm{~mL})$ bevacizumab was injected with a 30 -gauge insulin syringe placed $1.5 \mathrm{~mm}$ from the limbus, under sterile conditions. None of the patients required high-care observation, and all were discharged, home or to the referring hospital where they were being treated for other comorbidities not related to the IVB procedure, several hours after the injection. 
All patients were seen 5 days after the injection, and the follow-up period was doubled at each consecutive visit until the retina was fully vascularised (or up to 60 weeks' gestational age if the retinopathy responded favourably). If neovascularisation was still evident, laser treatment was given.

Outcome measures were complete regression of the proliferative phase and complete vascularisation of the retina.

A cost-effectiveness model was used to compare the cost of laser therapy with IVB. The cost was extrapolated from charges in a private hospital for the two procedures as well as current medical rates for follow-up visits. Public health sector costing was not possible. The preoperative preparation, intraoperative time and equipment used, postoperative need for high-care observation and length of follow-up were all calculated for the two groups.

Results were entered onto an Excel spreadsheet (2011, Microsoft, USA). Descriptive statistics were used for demographics.

\section{Table 1. Screening criteria for ROP}

Who to screen:

All neonates born $<32$ weeks' gestation

All preterm neonates weighing $<1500 \mathrm{~g}$

When to screen:

At 6 weeks' chronological age or 31 - 33 weeks' post-conceptual age (whichever comes later)

If gestational age is inaccurate, neonates $<28$ weeks' postconceptual age should be screened 6 weeks after birth and neonates $>28$ weeks' post-conceptual age should be screened 4 weeks after birth
Ethics approval was obtained from the Hospital Advisory Board (no reference number) and the Human Research Ethics Committee of the University of the Witwatersrand, Johannesburg (ref. no. M160306).

\section{Results}

Of 1911 patients screened over the study period, 23 (1.2\%) required treatment (Table 3). A total of 44 eyes received IVB injections, two patients requiring injections in only one eye. None of the infants required repeat injections for recurrences.

The mean birth weight was $1074 \mathrm{~g}$ (range 810 - 1 480) and the mean gestational age 28 weeks (range 26 - 32). Only two infants had birth weights of $>1250 \mathrm{~g}$. There were 13 males and 10 females.

Fourteen eyes had threshold disease and 28 had pre-threshold disease with plus disease (Table 3 ). Eighteen eyes had zone 1 disease and 26 had zone 2 disease requiring treatment.

The outcome of treatment was available for 22 patients (43 eyes); patient 10, with unilateral disease, defaulted (Table 3). Forty-one (95.3\%) of 43 eyes showed complete regression or non-progression of ROP. Two patients (two eyes) showed progression, patient 11 in one eye and patient 5 with unilateral disease (Table 3 ). Both developed retinal detachment within 1 week after injection. None of the infants required laser intervention. No short-term adverse events were noted during a mean follow-up of 9 months (range 1 - 18).

When considering the economic aspects of treating patients with IVB compared with laser ablation, the cost of the injection was ZAR12 529.83 (with the potential maximum number of visits) and the cost of laser therapy was ZAR25 916.03 (Table 4). The difference was mainly due to theatre time and the need for overnight high-care monitoring associated with laser treatment. IVB-treated neonates require more follow-up visits.

Table 2. Indications to treat ROP (based on international classification of ROP)

\begin{tabular}{|c|c|c|c|}
\hline & Stage of ROP & Zone & Plus disease \\
\hline $\begin{array}{l}\text { CRYO-ROP criteria }{ }^{[3]} \text { (threshold } \\
\text { disease) }\end{array}$ & $\begin{array}{l}3 \text { (new vessels in } 5 \text { contiguous or } \\
8 \text { non-contiguous clock hours) }\end{array}$ & 1 or 2 & Present \\
\hline \multirow{3}{*}{$\begin{array}{l}\text { ETROP criteria }{ }^{[4]} \text { (type } 1 \text { ROP - } \\
\text { pre-threshold disease) }\end{array}$} & Any & 1 & Present \\
\hline & 3 & 1 & Present or absent \\
\hline & 2 or 3 & 2 & Present \\
\hline
\end{tabular}

Table 3. Patient details

\begin{tabular}{|c|c|c|c|c|c|c|c|c|}
\hline Patient no. & Sex & $\begin{array}{l}\text { Birth } \\
\text { weight } \\
\text { (g) }\end{array}$ & $\begin{array}{l}\text { Gestational } \\
\text { age (wk) }\end{array}$ & $\begin{array}{l}\text { Stage at } \\
\text { presentation, } \\
\text { OD }\end{array}$ & $\begin{array}{l}\text { Stage at } \\
\text { presentation, } \\
\text { OS }\end{array}$ & Response to IVB & $\begin{array}{l}\text { Follow-up } \\
(\mathrm{mo})\end{array}$ & Vasularised \\
\hline 1 & $\mathrm{M}$ & 810 & 30 & $\begin{array}{l}\text { Zone } 1 \text { stage } 3 \\
\text { with plus }\end{array}$ & $\begin{array}{l}\text { Zone } 1 \text { stage } 3 \\
\text { with plus }\end{array}$ & Yes & 8 & Yes, within 3 mo \\
\hline 2 & $\mathrm{~F}$ & 1480 & 28 & $\begin{array}{l}\text { Zone } 1 \\
\text { threshold with } \\
\text { plus }\end{array}$ & $\begin{array}{l}\text { Zone } 1 \\
\text { threshold with } \\
\text { plus }\end{array}$ & Yes & 6 & Yes, within 3 mo \\
\hline 3 & M & 910 & 28 & $\begin{array}{l}\text { Zone } 1 \text { stage } 3 \\
\text { with plus }\end{array}$ & $\begin{array}{l}\text { Zone } 1 \text { stage } 3 \\
\text { with plus }\end{array}$ & Yes & 3 & Yes, within 2 mo \\
\hline 4 & $\mathrm{~F}$ & - & 26 & $\begin{array}{l}\text { Zone } 2 \text { stage } 3 \\
\text { with plus }\end{array}$ & $\begin{array}{l}\text { Zone } 2 \text { stage } 3 \\
\text { threshold with } \\
\text { plus }\end{array}$ & Yes & 6 & $\begin{array}{l}\text { Improved but still } \\
\text { not vascularised at } \\
\text { last follow-up }\end{array}$ \\
\hline $\begin{array}{l}5 \\
\text { (unilateral) }\end{array}$ & $\mathrm{F}$ & 960 & 27 & $\begin{array}{l}\text { Zone } 2 \text { stage } 1 \text {, } \\
\text { no plus }\end{array}$ & $\begin{array}{l}\text { Zone } 1 \text { stage } 3 \\
\text { with plus }\end{array}$ & $\begin{array}{l}\text { No, OS total retinal } \\
\text { detachment within } \\
1 \text { wk (Rush disease) }\end{array}$ & 6 & No \\
\hline
\end{tabular}


Table 3. (continued) Patient details

\begin{tabular}{|c|c|c|c|c|c|c|c|c|}
\hline Patient no. & Sex & $\begin{array}{l}\text { Birth } \\
\text { weight } \\
\text { (g) }\end{array}$ & $\begin{array}{l}\text { Gestational } \\
\text { age (wk) }\end{array}$ & $\begin{array}{l}\text { Stage at } \\
\text { presentation, } \\
\text { OD }\end{array}$ & $\begin{array}{l}\text { Stage at } \\
\text { presentation, } \\
\text { OS }\end{array}$ & Response to IVB & $\begin{array}{l}\text { Follow-up } \\
\text { (mo) }\end{array}$ & Vasularised \\
\hline 6 & $\mathrm{~F}$ & 1100 & 28 & $\begin{array}{l}\text { Zone } 2 \text { stage } 3 \\
\text { with plus }\end{array}$ & $\begin{array}{l}\text { Zone } 1 \text { stage } 3 \\
\text { with plus }\end{array}$ & Yes & 3 & Yes, within 3 mo \\
\hline 7 & $\mathrm{M}$ & 1250 & 31 & $\begin{array}{l}\text { Zone } 1 \text { stage } 3 \\
\text { with plus }\end{array}$ & $\begin{array}{l}\text { Zone } 1 \\
\text { threshold with } \\
\text { plus }\end{array}$ & Yes & 4 & Yes, within 4 mo \\
\hline 8 & $\mathrm{M}$ & 1160 & 30 & $\begin{array}{l}\text { Zone } 1 \text { stage } 3 \\
\text { with plus }\end{array}$ & $\begin{array}{l}\text { Zone } 1 \text { stage } 3 \\
\text { with plus }\end{array}$ & Yes & 3 & Yes, within 2 mo \\
\hline 9 & $\mathrm{~F}$ & 840 & 28 & $\begin{array}{l}\text { Zone } 2 \text { stage } 2 \\
\text { with plus }\end{array}$ & $\begin{array}{l}\text { Zone } 1 \text { stage } 3 \\
\text { threshold with } \\
\text { plus }\end{array}$ & Yes & 1 & Lost to follow-up \\
\hline $\begin{array}{l}10 \\
\text { (unilateral) }\end{array}$ & $\mathrm{M}$ & 885 & 29 & $\begin{array}{l}\text { Zone } 2 \\
\text { threshold with } \\
\text { plus }\end{array}$ & $\begin{array}{l}\text { Zone } 2 \text { stage } 2 \text {, } \\
\text { no plus }\end{array}$ & $\begin{array}{l}\text { Given OD only, } \\
\text { lost to follow-up }\end{array}$ & No & Lost to follow-up \\
\hline 11 & $\mathrm{M}$ & 1340 & 29 & $\begin{array}{l}\text { Zone } 1 \text { stage } 3 \\
\text { threshold with } \\
\text { plus }\end{array}$ & $\begin{array}{l}\text { Zone } 2 \text { stage } 3 \\
\text { with plus }\end{array}$ & $\begin{array}{l}\text { OD yes/OS Rush } \\
\text { disease stage } 4 b\end{array}$ & 1 & OD yes \\
\hline 12 & $\mathrm{~F}$ & 875 & 26 & $\begin{array}{l}\text { Zone } 2 \text { stage } 3 \\
\text { with plus }\end{array}$ & $\begin{array}{l}\text { Zone } 2 \text { stage } 3 \\
\text { with plus }\end{array}$ & Yes & 11 & Yes, within 3 mo \\
\hline 13 & $\mathrm{M}$ & 1390 & 32 & $\begin{array}{l}\text { Zone } 1 \text { stage } 3 \\
\text { with plus }\end{array}$ & $\begin{array}{l}\text { Zone } 1 \text { stage } 3 \\
\text { with plus }\end{array}$ & Yes & 1 & $\begin{array}{l}\text { No, lost to follow- } \\
\text { up }\end{array}$ \\
\hline 14 & M & 1040 & 27 & $\begin{array}{l}\text { Zone } 1 \text { stage } 3 \\
\text { with plus }\end{array}$ & $\begin{array}{l}\text { Zone } 1 \text { stage } 3 \\
\text { with plus }\end{array}$ & Yes & 5 & $\begin{array}{l}\text { No, demarcation } \\
\text { line peripheral } \\
\text { zone } 2\end{array}$ \\
\hline 15 & M & 1250 & 30 & $\begin{array}{l}\text { Zone } 2 \text { stage } 3 \\
\text { with plus }\end{array}$ & $\begin{array}{l}\text { Zone } 2 \text { stage } 1 \text {, } \\
\text { no plus }\end{array}$ & Yes & 2 & Yes, within 2 mo \\
\hline 16 & $\mathrm{~F}$ & 1085 & 26 & $\begin{array}{l}\text { Zone } 2 \text { stage } 3 \\
\text { with plus }\end{array}$ & $\begin{array}{l}\text { Zone } 2 \text { stage } 3 \\
\text { with plus }\end{array}$ & Yes & 2 & Yes, within 2 mo \\
\hline 17 & $\mathrm{~F}$ & 1195 & 29 & $\begin{array}{l}\text { Zone } 2 \text { stage } 3 \\
\text { threshold with } \\
\text { plus }\end{array}$ & $\begin{array}{l}\text { Zone } 2 \text { stage } 3 \\
\text { threshold with } \\
\text { plus }\end{array}$ & Yes & 11 & Yes, within 3 mo \\
\hline 18 & $\mathrm{M}$ & 1200 & 30 & $\begin{array}{l}\text { Zone } 2 \text { stage } 3 \\
\text { with plus }\end{array}$ & $\begin{array}{l}\text { Zone } 2 \text { stage } 3 \\
\text { with plus }\end{array}$ & Yes & 10 & Yes, within $1 \mathrm{mo}$ \\
\hline 19 & $\mathrm{M}$ & 840 & 26 & $\begin{array}{l}\text { Zone } 2 \text { stage } 3 \\
\text { with plus }\end{array}$ & $\begin{array}{l}\text { Zone } 2 \text { stage } 3 \\
\text { with pre-plus }\end{array}$ & Yes & 2 & $\begin{array}{l}\text { No, lost to follow- } \\
\text { up }\end{array}$ \\
\hline 20 & $\mathrm{~F}$ & 825 & 27 & $\begin{array}{l}\text { Zone } 2 \text { stage } 3 \\
\text { with plus }\end{array}$ & $\begin{array}{l}\text { Zone } 2 \text { stage } 3 \\
\text { with plus }\end{array}$ & Yes & 2 & Yes, within $1 \mathrm{mo}$ \\
\hline 21 & $\mathrm{M}$ & 1180 & 26 & $\begin{array}{l}\text { Zone } 2 \text { stage } 3 \\
\text { threshold with } \\
\text { plus }\end{array}$ & $\begin{array}{l}\text { Zone } 2 \text { stage } \\
3 \text { threshold } \\
\text { with plus } \\
\text { and vitreous } \\
\text { haemorrhage }\end{array}$ & Yes & 1 & $\begin{array}{l}\text { Lost to follow- } \\
\text { up (followed up } \\
\text { elsewhere) }\end{array}$ \\
\hline 22 & $\mathrm{M}$ & 829 & 29 & $\begin{array}{l}\text { Zone } 2 \\
\text { threshold with } \\
\text { plus }\end{array}$ & $\begin{array}{l}\text { Zone } 2 \\
\text { threshold with } \\
\text { plus }\end{array}$ & Yes & 18 & Yes, within 4 mo \\
\hline 23 & $\mathrm{~F}$ & 1190 & 27 & $\begin{array}{l}\text { Zone } 2 \text { stage } 3 \\
\text { with plus }\end{array}$ & $\begin{array}{l}\text { Zone } 2 \text { stage } 3 \\
\text { threshold with } \\
\text { plus }\end{array}$ & Yes & 8 & $\begin{array}{l}\text { No, not } \\
\text { vascularised at last } \\
\text { follow-up }\end{array}$ \\
\hline
\end{tabular}


Table 4. Cost analysis comparing laser therapy with IVB (ZAR)

\begin{tabular}{lll}
\hline & Laser & IVB \\
\hline Theatre fee & $16182.00(1.5 \mathrm{~h})$ & $1798.00(10 \mathrm{~min})$ \\
Medical stock & 7281.90 & 1231.83 \\
Neonatal high care & 7452.13 & - \\
Laser hire fee & 1500.00 & - \\
Cost of bevacizumab & - & 1000.00 \\
$\begin{array}{l}\text { Follow-up visits } \\
\text { (ZAR700.00/visit) }\end{array}$ & 3500.00 (average & 8400.00 (average \\
Total & 25916.03 & 12 visits) \\
& & 12529.83
\end{tabular}

\section{Discussion}

Our findings highlight several important issues regarding ROP in SA. Our study confirms previous findings that the incidence of severe ROP is low and that the current criteria of screening babies with a birth weight of $<1500 \mathrm{~g}$ are valid. ${ }^{[11]}$ Notwithstanding the potential risk factors, screening heavier babies would place an unnecessary burden on the limited pool of ophthalmologists screening for ROP.

Laser ablation is still the mainstay of treatment. The ETROP study showed the advantage of treating high-risk infants earlier with laser, reducing the risk of an unfavourable outcome from $15.6 \%$ to $9 \%$ compared with the initial CRYO-ROP recommendations. ${ }^{[12]}$ While laser therapy has been the treatment of choice for a number of years in our institution, every treatment event has a huge impact on our regular theatre list. A senior anaesthetist is needed, the procedure is time consuming, a special ambulance to transport the infant to a high-care facility is required, and high-care facility beds are not always available when they are needed.

Anti-VEGF injections have mainly been used for zone 1 disease, with good outcome. In a meta-analysis study, Alba et al. ${ }^{[13]}$ concluded that an anti-VEGF agent was more beneficial than laser therapy in stage $3+$ ROP in zone 1, but that there was no difference between the two in stage $3+$ ROP in zone $2 \cdot{ }^{[13]}$ In a study of 23 patients, Isaac et al. ${ }^{[14]}$ showed similar outcomes between laser therapy and anti-VEGF. The BEAT-ROP study was the first prospective randomised study to compare laser with IVB therapy. The findings showed a comparable outcome in the two groups with regard to efficacy and safety. ${ }^{[8]}$

We treated zone 1 and zone 2 type 1 disease with IVB, with favourable short-term outcomes. In our study $95.3 \%$ of patients showed complete regression with one injection. The BEAT-ROP study ${ }^{[8]}$ showed a recurrence of $6 \%$ at a mean of 16 weeks after the injection. In a Canadian study on involutional pattern of ROP following IVB injections, Isaac et al. ${ }^{[15]}$ reported recurrence in $61 \%$ of their patients. However, recurrences were stage 1 or 2 and none required retreatment. We did not observe any recurrence of the disease in our patients. The majority of our patients had complete vascularisation, only two patients showing incomplete vascularisation in zone 3 even after 6 months of follow-up. The two eyes with unfavourable results had aggressive posterior disease that progressed within 1 week of the injection.

The safety profile of anti-VEGF use in ROP is still of concern. IVB has been reported to suppress serum levels of VEGF for up to
2 months after the injection. ${ }^{[16]}$ In another study, Menke et al. ${ }^{[17]}$ attributed upper respiratory infection in one patient as a possible complication. The BEAT-ROP study established the safety profile of IVB, finding no systemic side-effects at the 3-year follow up. However, long-term side-effects have not been established. None of our patients developed short-term complications attributed to IVB.

There has been no report on the logistical advantage of IVB therapy over laser, in terms of resources or cost. Our study shows a clear benefit of IVB over laser, the cost of laser therapy being twice as high, although follow-up visits are more frequent with IVB.

\section{Study limitations}

Limitations of the study are its retrospective nature and the lack of fluorescein angiography to document full vascularisation, as well as loss to follow-up of 2 patients.

\section{Conclusion}

Our study demonstrates that the use of IVB as an anti-VEGF agent in the treatment of ROP is effective and safe. In resource-limited centres, the use of IVB as first-line therapy in all type 1 disease may be more practical than laser therapy with regard to both clinical management and the economic burden of treatment.

\footnotetext{
1. O'Sullivan J, Gilbert C, Foster A. The causes of childhood blindness in South Africa. S Afr Med J 1997;87(12):1691-1695.

2. Gilbert C, Foster A. Childhood blindness in the context of VISION 2020 - the right to sight. Bull World Health Organ 2001;79(3):227-232.

3. Cryotherapy for Retinopathy of Prematurity Cooperative Group. Multicenter trial of cryotherapy for retinopathy of prematurity: Natural history ROP: Ocular outcome at 5(1/2) years in premature infants with birth weights less than $1251 \mathrm{~g}$. Arch Ophthalmol 2002;120(5):595-599.

4. Early Treatment for Retinopathy of Prematurity Cooperative Group, Good WV, Hardy RJ, Dobson $\mathrm{V}$, et al. Final visual acuity results in the early treatment for retinopathy of prematurity study. Arch Ophthalmol 2010;128(6):663-671. http://dx.doi.org/10.1001/archophthalmol.2010.34

5. Ferrara N, Hillan KJ, Gerber H-P, Novotny W. Discovery and development of bevacizumab, an anti-VEGF antibody for treating cancer. Nat Rev Drug Discov 2004;3(5):391-400. http://dx.doi. org $/ 10.1038 /$ nrd 1381

6. Brown DM, Campochiaro PA, Singh RP, et al. Ranibizumab for macular edema following central retinal vein occlusion: Six-month primary end point results of a phase III study. Ophthalmology 2010;117(6):1124-1133. http://dx.doi.org/10.1016/j.ophtha.2010.02.022

7. Jampol LM, Glassman AR, Bressler NM. Comparative effectiveness trial for diabetic macular edema: Three comparisons for the price of 1 study from the Diabetic Retinopathy Clinical Research Network. Three comparisons for the price of 1 study from the Diabetic Retinopathy Clinical Research Network.
JAMA Ophthalmol 2015;133(9):983-984. http://dx.doi.org/10.1001/jamaophthalmol.2015.1880

8. Mintz-Hittner HA, Kennedy KA, Chuang AZ, BEAT-ROP Cooperative Group. Efficacy of 8. Mintz-Hittner HA, Kennedy KA, Chuang AZ, BEAT-ROP Cooperative Group. Efficacy of
intravitreal bevacizumab for stage 3+ retinopathy of prematurity. N Engl J Med 2011;364(7):603615. http://dx.doi.org/10.1056/NEJMoa1007374

9. Bancalari MA, Schade YR, Peña ZR, Pavez PN. [Intravitreal bevacizumab as single drug therapy for retinopathy of prematurity in 12 patients.] Arch Argent Pediatr 2014;112(2):160-163. http://dx.doi. org/10.5546/aap.2014.160

10. Baumal CR, Goldberg RA, Fein JG. Primary intravitreal ranibizumab for high-risk retinopathy of prematurity. Ophthalmic Surg Lasers Imaging Retina 2015;46(4):432-438. http://dx.doi. org $/ 10.3928 / 23258160-20150422-5$

11. Mayet I, Cockinos C. Retinopathy of prematurity in South Africans at a tertiary hospital: A prospective study. Eye (Lond) 2006;20(1):29-31. http://dx.doi.org/10.1038/sj.eye.6701779

12. Good WV, Early Treatment for Retinopathy of Prematurity Cooperative Group. Final results of the Early Treatment for Retinopathy of Prematurity (ETROP) randomized trial. Trans Am Ophthalmol Soc 2004;102:233-250.

13. Alba LE, Zaldua RA, Masini RA. [Off-label use of intravitreal bevacizumab for severe retinopathy of Alba LE, Zaldua RA, Masini RA. [Off-label use of intravitreal bevacizumab for severe retinopathy of
prematurity.] Arch Soc Esp Oftalmol 2015;90(2):81-86. http://dx.doi.org/10.1016/j.oftal.2014.09.011 14. Isaac M, Mireskandari K, Tehrani N. Treatment of type 1 retinopathy of prematurity with bevacizumab 4. Isaac M, Mireskandari K, Tehrani N. Treatment of type 1 retinopathy of prematurity with bevacizus
versus laser. J AAPOS 2015;19(2):140-144. http://dx. doi.org/10.1016/j.jaapos.2015.01.009

15. Isaac M, Tehrani N, Mireskandari K. Involution patterns of retinopathy of prematurity after treatment with intravitreal bevacizumab: Implications for follow-up. Eye (Lond) 2016;30(3):333-341. http:// dx.doi.org/10.1038/eye.2015.289

16. Wu W-C, Lien R, Liao P-J, et al. Serum levels of vascular endothelial growth factor and related factors after intravitreous bevacizumab injection for retinopathy of prematurity. JAMA Ophthalmol 2015;133(4):391-397. http://dx.doi.org/10.1001/jamaophthalmol.2014.5373

17. Menke MN, Framme C, Nelle M, et al. Intravitreal ranibizumab monotherapy to treat retinopathy of prematurity zone II, stage 3 with plus disease. BMC Ophthalmol 2015;15:20. http://dx.doi.
} org/10.1186/s12886-015-0001-7

Accepted 20 September 2016. 